\title{
An Empirical Investigation of Supervisory Management Styles and Associated Factors for Postgraduate Level Research Supervision
}

\author{
Tooba Saleem ${ }^{*}$ \\ Rizwan Akram Rana*
}

\begin{abstract}
Based on the dynamic model of supervisory management styles this research focused on the empirical verification of the preferred supervisory management styles and their associated baseline characteristics of supervisors and supervisees. The study used a mixedmethods research approach and was conducted in two phases. In the first phase, semi-structured interviews were conducted from 30 supervisors from different disciplines to get an overview of the context specific supervision problems faced by supervisors and their approaches to solve them during the different research stages. These interviews helped to develop items of supervisory management styles questionnaire (SMSQ). This questionnaire was based on 12 different situations. In the second phase, supervisors and supervisees from 13 different universities of the Punjab were selected purposively to respond to the supervisory management styles questionnaire. The chi-square tests were performed to analyze the preferred supervisory management styles and their association with personal, academic and institutional characteristics of supervisors and supervisees. The results showed significant influence of the supervisees' background profile characteristics and supervisors' administrative position on the adoption of a particular supervisory management style at postgraduate level. The study identified the baseline characteristics associated with different supervision styles that may help to resolve possible supervisory alignment conflicts.
\end{abstract}

Keywords: supervisory management styles, pedagogical manifestations, $\mathrm{PhD}$ supervision, supervision characteristics

*Lecturer, Secondary Teacher Education Department, Allama Iqbal Open University. Islamabad.Email: tooba_malik90@hotmail.com

*** Professor University of the Punjab,drrarpu@gmail.com 


\section{Introduction}

The significance of supervisor-supervisee relationship has been acknowledged in many research studies (Hemer, 2012; Malfroy, 2005; McAlpine \& McKinnon, 2013). However, the nature of supervisory relationship is not simple, it is complex and influenced by various factors (Abdulla \& Evans, 2012; Saleem \& Mahmood, 2017; Saleem \& Mahmood, 2018). Grant (2003) mapped out four layers of supervisory relationship that function within supervision. The first layer is the most visible one that constructs supervision between a supervisor and supervisee that works under the institutional code of practice like procedures of supervisor allotment etc. (Ives \& Rowley, 2005; Saleem \& Mahmood, 2017). The second layer of supervision can be attributed by the pedagogical power relations build up between the supervisor and supervisee. The third layer of relationship takes account of the "diverse social positions" adopted by a supervisor and supervisee, producing complicated and unpredictable interactions. The fourth and final layer has been explained as inexplicable yet influential operation of supervisors and supervisee' conscious and unconscious associated knowing and desires. Hence, the working relationship between supervisor and supervisee involves complexities in the form of personal, institutional and academic competence that cannot be operated in the same way.

In this context, previously studies which have been conducted in Pakistan identified the significance of a match between supervisor's area of research and supervisees' research topic, particular stage of research and study discipline (Saleem \& Mahmood, 2017; Saleem \& Mahmood, 2018 ) as the visible factors that influence the supervisory relationship. However, less has been researched upon the invisible layers of supervisory relationship and its elements in the past.

\section{Literature Review}

\section{Supervisory Management Styles and Models}

In the backdrop of these complexities and supervision process, an essential element that is invisible, more abstract but equally important for the efficiency and effectiveness of supervision at postgraduate level is the mutual alignment of supervisor and supervisees (Gurr, 2001; Kam, 1997; Lee, 2007) in supervisory relationship and the way supervisors manage their supervisees' research projects and support them to complete their research successfully (Gatfield, 2005). The authors (Andreson, 1988; Arenda-Mena \&Gameson, 2012; Boehe, 2016; Deuchar, 2008; Grant, 2005; Gurr, 2001) presented various supervision models in the context of research supervision pedagogy and the related problems with main focus on adjustment in 
supervisory relationship and addressing the dynamic needs of supervisees with different approaches. A brief description of supervision styles and models has been presented below in table 1:

Table 1

Research Supervision Pedagogy: Styles and Models

\begin{tabular}{|c|c|c|}
\hline Authors & Styles/models & Specific Supervision Characteristics \\
\hline $\begin{array}{l}\text { Anderason } \\
(1988)\end{array}$ & $\begin{array}{l}\text { Continuum of Supervision } \\
\text { Model }\end{array}$ & $\begin{array}{l}\text { Helped supervisors and supervisees to know } \\
\text { their own perspectives and behaviors towards } \\
\text { supervision as direct/indirect-active/passive }\end{array}$ \\
\hline Kam (1997) & Supervision Style & $\begin{array}{l}\text { The element of supervisees' independence and } \\
\text { dependence on supervisor and the way } \\
\text { supervisor manage supervision process. }\end{array}$ \\
\hline Lee (1999) & $\begin{array}{l}\text { Supervision Approaches/ } \\
\text { Apprenticeship Style }\end{array}$ & $\begin{array}{l}\text { Four Supervision Approaches of Supervisors: } \\
\text { 1) Functional: priority is project } \\
\text { management; } \\
\text { 2) Enculturation: encouraging students to } \\
\text { involve in disciplinary community; } \\
\text { 3) Critical thinking: encouraging students to } \\
\text { question and analyze their work; } \\
\text { 4) Emancipation: encouraging students to } \\
\text { question and develop their minds }\end{array}$ \\
\hline Gurr (2001) & $\begin{array}{l}\text { Supervisor/Student } \\
\text { Alignment: Dynamic } \\
\text { Model }\end{array}$ & $\begin{array}{l}\text { Alignment tool: For aligning supervisory style } \\
\text { with research student development. }\end{array}$ \\
\hline Gatfield (2005) & $\begin{array}{l}\text { Dynamic Supervisory } \\
\text { Management Conceptual } \\
\text { Model }\end{array}$ & $\begin{array}{l}\text { Two-dimensional Conceptual Model based on } \\
\text { Blake and Moulton's (1964) managerial grid: } \\
\text { Four Supervision Management Styles were } \\
\text { identified i.e. } \\
\text { 1) Liassez-faire: low structure low support } \\
\text { 2) Pastoral: low structure high support } \\
\text { 3) Directorial: high structure low support } \\
\text { 4) Contractual: high structure high support }\end{array}$ \\
\hline Deuchar (2008) & $\begin{array}{l}\text { Contradiction and } \\
\text { congruence in doctoral } \\
\text { supervision styles }\end{array}$ & $\begin{array}{l}\text { Analysis of Different Approaches } \\
\text { Supervision journey hand-on and hands off } \\
\text { approach }\end{array}$ \\
\hline $\begin{array}{l}\text { Aranda-Mena } \\
\text { and Gameson } \\
(2012)\end{array}$ & $\begin{array}{l}\text { supervisor-student } \\
\text { alignment model }\end{array}$ & $\begin{array}{l}\text { The Repertory Grid Technique (RGT) } \\
\text { consisting elements of Support and } \\
\text { Engagement that influence supervisory } \\
\text { relationship and completion. }\end{array}$ \\
\hline Boehe (2016) & $\begin{array}{l}\text { Contingency Framework } \\
\text { of Supervision Styles }\end{array}$ & $\begin{array}{l}\text { Based on behavioral contingency theory, } \\
\text { develop Contingency Framework of } \\
\text { Supervision Styles by addressing the } \\
\text { contingency factors. The process and product } \\
\text { related contingency factors }\end{array}$ \\
\hline
\end{tabular}

It can be understood from the brief review on styles and models that different supervision styles comes up with different elements of supervision and supervisors should adopt different styles and approaches in order to meet the needs of supervisees. Across the continuum of 
research process, in the initial stage supervisees need more supervision support and pastoral care.

Supervisors may also prefer to use scaffolding procedure, where they feel better to provide support to supervisees in the initial stages of research but later on expect them to become more independent. This approach is particularly important in the context of social sciences discipline, where the problem of intellectual isolation and lack of critical mass of associated scholars in a specific research area often are more common (Parry \& Hayden, 1994).

While, there have been other contextual factors associated with supervisees' threshold concepts about research and motivation and the supervisors perceived good supervision practices that influence the supervisors' take towards preferred operating styles. There has been an increasing recognition about supervisors need to be flexible and adaptable according to situations. Thus, the selection of a supervision style and its success not only depending upon the visible factors but also influence by the internal dynamics of the supervisory relationship that are explained through the different layers of relationship. In this context, the relationship between a supervisors and supervisee (Grant, 1999) can be assimilated with the process of negotiating like "walking on a rackety bridge".

Results suggested that students want both structure and support, which may challenge some supervisors who see their role as moving the novice student through dependency and interdependency to full independence as a researcher (Grant, 2005; Lee, 2008; Moriarty, Danaher \& Danaher, 2008). What stands out is that supervisors need to be adaptable and supervision style discussed openly to ensure compatibility that meets the need of both parties (Deuchar, 2008).

\section{Personal, Academic and Institutional Factors Associated with Research Supervision}

Supervision approach of a supervisor can be viewed as pedagogy that change with different research candidates due to difference in the interaction between supervisor and supervisee and the power relations in terms of the knowledge (Murphey, Bain \& Conrad, 2007) and their social positions (Grant, 2003). The possible sources of variation come from the external environment as supervision approaches or styles are not the inherent (Gatifield, 2005). In this context, in order to resolve alignment issues between supervisor and supervisee there is a need to 
understand the factors associated with the supervision management styles of supervisors.

Gatfield (2005) also acknowledged these factors as "external" which are related to the individuals' aspects like motivation, research skills and maturity level. Moreover, adoption of a style by supervisor is also influenced by the characteristics of supervisees and their particular stage of research. In other researches (Aranda-Mena \&Gameson, 2012; Boehe, 2016; Grant, 2003; Gurr, 2001) the dynamic needs of supervisees have also been recognized and use of different styles has been considered appropriate at specific time with specific purposes.

Gurr (2001) further explained that a more directive approach is appropriate to supervise when needs to demonstrate new knowledge or application of a software or analysis is require. While in the later stages when supervisees progressed towards becoming peer a more hands-off approach is appropriate to supervisee's level of development. This would be result into developing confidence for decision making about project, ownership and responsibility. If supervisors do not make these essential change in the supervision approaches may stifle the academic development of supervisees or becoming a cause of conflict in supervisory relationship. In some cases using static supervision approach can hinder the academic growth of supervisees.

The notion is also endorsed by Linden, Ohlin and Brodin (2013) the purpose of $\mathrm{PhD}$ is to develop the students for the professional work but unfortunately, their personal learning and development are not supported considerably. Discussing the desirable qualities of supervisors in USA Taylor, Vitale, Tapoler and Whaley (2018) reported the research candidates rated Laissez-faire and autocratic as lowest raked supervision styles. Moreover, in modern PhD programmes the increasing number of professionals and part-time candidates' status impact their relationship as these candidates are not necessarily available for their supervisors to do other work activities like the traditional full time candidates. Early career academicians involved in research supervision primarily depends upon their own experiences as doctoral student their limited exposure towards supervision perceived to be not prepared for the role and expressing low clarity about the concerned standards or the right was to do it (Blass, Jasman\& Levy, 2012). However, supervisors in their early careers were found agentive, devoting in setting goals and supporting their students and more resilient (Turner, 2015). Benmore (2016) explained the concept of supervisory roles and their transition during the research journey that depends upon the supervisors' personal motives and candidates' experience and academic credentials. 
On the supervisees' side there may be two type students i) who are pursuing their careers and ii) those with having less appeal towards their career (Mason, Goulden \& Frasch, 2009) but here the supervisor's role is to be sufficiently hands off, but not hiding themselves must knowing that when and how feedback is required otherwise supervisor' absenteeism can hamper the progress of their students. Wright and Cochrane (2000) examined the factor contributing significantly in the successful timely completion of $\mathrm{PhD}$ were study discipline, age and the source of funding in western context. Students from science discipline were found more likely to submit their PhDs within four years as compared to the students in arts and social sciences disciplines. The students in their early age (2630) were found more likely to complete their degrees in time as compare to the older students. It has been also recognized that element of dissatisfaction is generally reported higher by the research candidates in social science than in natural sciences (Saleem \& Mahmood, 2017) supervision itself has been regarded as "the single most important variable affecting the success of the research process in the social sciences". It has been described as "probably the most responsible task undertaken by an academic".

It has been reported in a study conducted by Mainhard, Rijst, Tartwijk and Wubbels (2009) based on a supervisor-doctoral student relationship model in context of background profile variables, pointed females supervisors as more influential than male and students reported these female supervisors conduct meetings with supervisees more frequently.

Gurr (2001) identified the dynamic need of supervision across the different stages of the research supervision and extracted from data that supervisees want to be more dependent in the initial stage of research and then move back to again this position of dependency when start writing up their thesis. So, it can be inferred that research stages play a significant role in determining the supervision needs. Over the period of supervision, the increased trend of development of supervisees into competent autonomy as a result of more hands off supervision approach.

Cantwell, Bourke, Scevak, Holbrook and Budd (2015) studied doctoral candidates' leaning and management with respect to their background characteristics. Three types of clusters i.e. affective management, cognitive management and contingency management were identified in the selected sample. It was found that gender plays no role in the membership of three identified clusters of the research candidates. While age-wise analysis of clusters membership was found significant and the candidates in group $40+$ were found more associated with 
constructively engaged cluster exhibiting a positive and constructive approach towards the research tasks believing them as do-able and intellectually manageable as compared to the younger research candidates who were more associated with disengaged and struggling to engage clusters. In addition to this, a significant difference was found in the membership of three different clusters on the basis of research candidates' stage of research i.e. early, middle and late. The candidates in the early stage of research were found significantly in higher proportion in the cluster struggling to engage and lower proportion in disengaged cluster. In the middle stage a higher proportion of supervisees found in disengaged cluster who thought that research tasks are un-do able for them and diminished sense of cognitive and affective control. They further reported that part-time students were more constructively engaged in affective and intellectual management of degree as compared to the full-time students. Hockey (1991) highlighted the importance of some personal attributes of research candidates while selecting them to supervise i.e. strong motivation towards research, independence, self confidence, persistence and ability of judgment.

\section{Gaps in Previous Researches}

Previously, the literature with the pedagogical concerns in research supervision thrives on the theoretical models and supervision styles (Andreson, 1988; Boehe, 2016; Deuchar, 2008; Gatfield, 2005; Grant, 2003; Gurr, 2001; Lee, 2007) and the supervision components related to the "structure" and "support" in western context. In some researches on doctoral supervision the associated background variables have been identified like Hockey (1991) pointed out some personal attributes of research candidates while selecting them to supervise i.e. strong motivation towards research, independence, self confidence, persistence and ability of judgment. In the context of supervision styles (ArandaMena \& Gameson, 2009; Boehe, 2016; Grant, 2003; Saleem \& Mahmood, 2018) emphasized the importance of various stages of research supervision with dynamic needs of supervisees and use of different styles has been considered appropriate at specific time with specific purposes. But in some of these researches the focus was only supervision experiences or in the other only supervision styles were focused. Hence, there needs to bridge the gap by consolidating the identified supervision styles and the associated factors that influence the supervision management choices of supervisors.

Moreover, methodologically these researches (Andreson, 1988; Boehe, 2016; Deuchar, 2008; Gatfield, 2005; Grant, 2003; Gurr, 2001; 
Lee, 2007) were qualitative in nature, conducted with small samples and mostly using theoretical approach to investigate supervisory management styles. Some other limitations of the previous researches have also been identified by Gatfield (2005) for example he pointed a need for empirical verification of the conceptual framework with a large sample in a nonwestern context was also suggested. Additionally, the model also suggested a need for extension studies especially in the context of developing countries with indigenous set of indicators, rigorous framework and empirical tools to examine the supervisory management styles. There was a gap in existing literature to chalk out the external factors which may be associated with supervisors' selection towards various styles during supervision.

The pedagogical manifestations that contribute towards the preferred choices towards supervision styles understanding the doctoral supervision practices that could direct the training and development of doctoral supervisors in Pakistani context as a worthwhile contribution towards the contemporary supervision management practices and to improve the doctoral degrees in a more complex, diverse, competitive and neo-liberal higher education environment. For this purpose, Dynamic Supervisory Management Conceptual Model of Gatfield (2005) was used to peruse empirical investigation of supervision styles.

\section{Research Questions and Hypotheses}

1. Which is the most preferred supervisory management style of supervisors at postgraduate level?

$\mathrm{H}_{01}$ : There is no significant preferred supervisory management style of supervisors at postgraduate level.

2. Is there any association between the background characteristics of supervisors and their preferred operating supervisory management style (SMS) at postgraduate level?

$\mathrm{H}_{02}$ : There is no significant association between background characteristics of supervisors and their preferred supervisory management style at postgraduate level.

3. Are the background characteristics of supervisees associated with the supervisory management style (SMS) of their supervisors at postgraduate level?

$\mathrm{H}_{03}$ : There is no significant association between background characteristics of supervisees and the preferred supervisory management style of their supervisors at postgraduate level. 


\section{Research Methodology Study Design}

We used the embedded mixed-methods design to collect and analyze data. In this design, one kind (qualitative or quantitative) of data set provides a supportive, secondary role in a single study based primarily on the other data type of data set (Creswell, Plano Clark, et al., 2003). Hence, this design is specifically useful in situations when researchers need to embed a qualitative component within a quantitative design. This approach in sequential manner is particularly useful when qualitative information is needed to develop an instrument for quantitative study.

\section{Sample of Study}

There are total 25 public and 24 private universities with $3434 \mathrm{PhD}$ faculty members in the Punjab (HEC, 2016). More than 500 supervisors were approached to collect data. A total of 302 supervisors (that is almost $10 \%$ of the total $\mathrm{PhD}$ faculty 3434 in 49 Universities of the Punjab) were selected purposively based on the supervision experience at postgraduate level from eight public and five private universities to investigate the research supervision styles of supervisors. The main characteristics of sample are given in table 2.

Table 2

Sample Characteristics of Supervisors

\begin{tabular}{|c|c|c|c|c|c|}
\hline $\begin{array}{l}\text { Background } \\
\text { Characteristics of } \\
\text { Supervisors }\end{array}$ & $\begin{array}{l}\mathrm{N}= \\
302\end{array}$ & $\begin{array}{l}\text { Non- } \\
\text { response } \\
\text { cases }\end{array}$ & $\begin{array}{l}\text { Background } \\
\text { Characteristics of } \\
\text { Supervisors }\end{array}$ & $\begin{array}{l}\mathrm{N}= \\
302\end{array}$ & $\begin{array}{l}\text { Non- } \\
\text { response } \\
\text { cases }\end{array}$ \\
\hline Gender & & & $\begin{array}{l}\text { Postgraduate Research } \\
\text { Supervision Experience }\end{array}$ & & \\
\hline Female & 100 & 5 & Up to 5 years & 158 & 13 \\
\hline Male & 197 & & $6-10$ years & 68 & \\
\hline Age(in years) & & & $11-15$ years & 32 & \\
\hline Below 30 & 1 & & $15-20$ years & 25 & \\
\hline $30-35$ & 67 & 0 & More than 20 years & 6 & \\
\hline $36-40$ & 89 & & $\begin{array}{l}\text { Administrative } \\
\text { Responsibility/ Post }\end{array}$ & & \\
\hline $41-45$ & 56 & & Chairperson & 47 & 38 \\
\hline $46-50$ & 33 & & Dean & 8 & \\
\hline $51-55$ & 32 & & Program Coordinator & 65 & \\
\hline above 55 & 14 & & Director & 12 & \\
\hline Discipline & & & Any other & 45 & \\
\hline Physical Sciences & 65 & 9 & Not any & 87 & \\
\hline $\begin{array}{l}\text { Management } \\
\text { Sciences }\end{array}$ & 31 & & University Sector & & \\
\hline
\end{tabular}




\begin{tabular}{lrllrc}
\hline $\begin{array}{l}\text { Background } \\
\text { Characteristics of }\end{array}$ & $\begin{array}{l}\mathrm{N}= \\
302\end{array}$ & $\begin{array}{l}\text { Non- } \\
\text { response } \\
\text { cases }\end{array}$ & $\begin{array}{l}\text { Background } \\
\text { Characteristics of } \\
\text { Supervisors }\end{array}$ & $\begin{array}{l}\mathrm{N}= \\
302\end{array}$ & $\begin{array}{l}\text { Non- } \\
\text { response } \\
\text { cases }\end{array}$ \\
\hline Social Sciences & 136 & & Public & 210 & 3 \\
Arts \& Humanities & 33 & & Private & 89 & \\
Life Sciences & 28 & & Teaching Workload(Credit Hours) \\
Designation & & & Up to 3 credit Hours & 14 & 52 \\
Lecturer & 46 & 6 & 4-6 Credit Hours & 27 & \\
Assistant Professor & 188 & & 7-9 Credit Hours & 69 & \\
Associate Professor & 36 & & 10-12 Credit Hours & 67 & \\
Professor & 26 & & Above 12 Credit Hours & 73 & \\
\hline
\end{tabular}

A subsequent sample of 136 supervisees under the supervision of sampled supervisors were given a profile performa to examine the association between the profile variables and the preferred supervisory management styles of supervisors. Following characteristics were included in the given performa.

Table 3

Sample Characteristics of Supervisees

\begin{tabular}{|c|c|c|c|c|c|}
\hline $\begin{array}{l}\text { Background } \\
\text { Characteristic } \\
\mathrm{s}\end{array}$ & $\begin{array}{l}\mathrm{N}= \\
136\end{array}$ & $\begin{array}{l}\text { Non- } \\
\text { response } \\
\text { cases }\end{array}$ & $\begin{array}{l}\text { Background } \\
\text { Characteristics }\end{array}$ & $\begin{array}{l}N=13 \\
6\end{array}$ & $\begin{array}{l}\text { Non- } \\
\text { response } \\
\text { cases } \\
\end{array}$ \\
\hline Gender & & & Study Discipline & & \\
\hline Female & 104 & 0 & Physical Sciences & 20 & 2 \\
\hline Male & 32 & & Management Sciences & 6 & \\
\hline Age (in years) & & & Social Sciences & 64 & \\
\hline $20-25$ & 49 & 0 & Arts \& Humanities & 26 & \\
\hline $26-30$ & 47 & & Life Sciences & 18 & \\
\hline $31-35$ & 24 & & Candidature Type & & \\
\hline $35-40$ & 14 & & Part Time & 20 & 4 \\
\hline $40-45$ & 2 & & Fulltime & 112 & \\
\hline Marital Status & & & Previous Research Exp & ence & \\
\hline Single & 90 & 9 & Yes & 45 & 0 \\
\hline Married & 37 & & No & 90 & 0 \\
\hline
\end{tabular}

\section{Instrumentation}

Supervisory Management Styles Questionnaire (SMSQ) was developed by researchers to empirically verify the supervision styles of supervisors. Semi-structured interview were conducted from 30 supervisors to explore: 1) the supervision problems faced by supervisors and 2) the way supervisors respond to these problems during the different stages of the research supervision process. The two way supervisory management styles grid (Gatfield, 2005) was used to yield 
the interviews' data into a framework of indicators through open and axial coding. Keeping these two dimensions (i.e. structure and support) in view the "Supervisory Management Style Questionnaire" (SMSQ) was developed. The items of SMSQ were based on twelve different situations that arise during different stages of research supervision process. The supervisors were supposed to respond to those situations according to their preferable supervision style. Each situation contained four options comprising four distinctive supervisory management styles i.e. depicting the aspects related to two dimensions "structure and support". Following situations from tool are given for example.

\begin{tabular}{|c|c|c|}
\hline Sr. & Situation & Alternative Actions \\
\hline 1. & $\begin{array}{l}\text { At synopsis development stage } \\
\text { your supervisee is stuck in } \\
\text { sorting the issues of research } \\
\text { methodology, meanwhile time } \\
\text { is running short and the } \\
\text { submission date is around what } \\
\text { would be your strategy to sort } \\
\text { out the issue? } \\
\text { Comment if you have done }\end{array}$ & $\begin{array}{l}\text { A. Increase the frequency of meetings with } \\
\text { close supervision } \\
\text { B. Mutual discussions and solutions would } \\
\text { emphasize over submission deadline } \\
\text { C. Allow the student to take time and } \\
\text { formulate work in his/her own direction } \\
\text { D. Engage the supervisee with high } \\
\text { interaction and bound to meet deadline } \\
\text { or supposed to do something else: }\end{array}$ \\
\hline \multicolumn{3}{|c|}{$\begin{array}{l}\text { Validity and Reliability of Supervisory Management Styles Questionnaire } \\
\text { (SMSO) }\end{array}$} \\
\hline \multicolumn{3}{|c|}{$\begin{array}{l}\text { Content validity of SMSQ were examine through expert opinion of } \\
\text { teachers supervising at postgraduate level at the Institute of Education and } \\
\text { Research, University of the Punjab, Lahore and Allama Iqbal Open } \\
\text { University, Islamabad. The experts were supervising multiple students and } \\
\text { were from the faculty of Education. The intra-rater measure of reliability } \\
\text { of supervision styles of } 12 \text { supervisors was assessed by giving them SMSQ } \\
\text { twice. The gap between conducting the tool twice was } 4-5 \text { weeks. The } \\
\text { intra-rater reliability value Cohen's kappa }=.721 \text { was found good to } \\
\text { measure the consistency of supervision styles of supervisors overtime. }\end{array}$} \\
\hline
\end{tabular}

\section{Study Procedure}

The study was conducted in two phases. In phase one, supervisors $(N=30)$ were interviewed and the interview data were used to develop Supervisory Management Styles Questionnaire (SMSQ). In the second phase, Supervisory Management Styles Questionnaire was distributed among 500 supervisors. Among them, 302 supervisors responded to it. A subsequent sample of 136 supervisees working under the supervision of pre-selected sample of supervisors, were given profile Performa. A prior 
consent from supervisors and supervisees was taken and they were ensured about confidentiality of information.

\section{Data Analysis and Results}

First, Chi-square test for goodness of fit was performed to investigate the preferred Supervisory Management Styles (SMS) of supervisors $(\mathrm{N}=250)$ in the selected sample. Further, Chi-square tests of Independence were conducted to examine the association between the supervisory management styles with various supervision related profile characteristics of supervisors and supervisees.

Table 4

Preferred Supervisory Management Style (SMS) of Supervisors at Postgraduate Level

\begin{tabular}{|c|c|c|c|c|c|}
\hline $\begin{array}{ll}\text { Supervisory } & N^{*} \\
\text { Management Style } & \end{array}$ & $\mathrm{n}_{\mathrm{o}}$ & $\mathrm{n}_{\mathrm{e}}$ & $d f$ & $\chi^{2}$ & $p$ \\
\hline Laissez-faire Style & 14 & 62.5 & 3 & $241.680^{\mathrm{a}}$ & .000 \\
\hline Pastoral Style & 46 & 62.5 & & & \\
\hline Directorial Style & 23 & 62.5 & & & \\
\hline Contractual Style & 167 & 62.5 & & & \\
\hline
\end{tabular}

a. 0 cells $(0.0 \%)$ have expected frequencies less than 5 . The minimum expected cell frequency is 62.5 .

*total number of respondents $=(250) ;\left(n_{0}\right)=$ Observed frequencies; Expected frequencies $=\left(\mathrm{n}_{\mathrm{e}}\right)$

A chi-square goodness-of-fit test was run to compare the observed frequencies or proportions of cases that would be expected for the four supervisory management styles of supervisors at postgraduate level. The alpha value $(p=.000)$ indicates that there is a significant difference in the proportion of expected and observed frequencies for the four supervisory management styles of supervisors identified in the current sample $(3, n=$ $250)=241.680^{\mathrm{a}}, p<.05$. For the contractual style the observed frequencies $\left(\mathrm{n}_{\mathrm{o}}=167\right)$ were higher than the expected frequencies $\left(\mathrm{n}_{\mathrm{e}}=62.5\right)$. According to $x^{2}$ Fitness of Good test the null hypothesis was rejected and it can be inferred that supervisors at postgraduate level prefer to use contractual style to supervise their research students.

\section{Supervisory Management Styles and Supervision Characteris- tics of Supervisors}

Chi-Square test of Independence was applied for analyzing the association of Supervisory Management Styles (SMS) with different 
categorical supervision characteristics (background variables) of supervisors at alpha $(\mathrm{p}<.05)$ value of significance along their effect size and chi-square $\left(x^{2}\right)$ value were used to interpret the results. Cramer's V value, effect size measure was taken into account as the cross-tables were larger than 2 by 2 . This measure is considered appropriate to report in such situations. It takes into account the degrees of freedom. Slightly different criteria are recommended for judging the size of the effect for larger tables (Gravetter \& Wallnau, 2004; Pallant, 2011).

Table 5

Chi-square Tests of Independence for Profile Characteristics of Supervisors and Supervisory Management Styles Adopted by Supervisors at Postgraduate Level

\begin{tabular}{|c|c|c|c|c|c|c|c|c|}
\hline \multirow{2}{*}{$\begin{array}{l}\text { Profile } \\
\text { Characteristics } \\
\text { Of Supervisors }\end{array}$} & \multicolumn{4}{|c|}{ Supervisory Management Style } & \multirow{2}{*}{\multicolumn{2}{|c|}{$d f . x^{2}$}} & \multirow[b]{2}{*}{$p$} & \multirow[b]{2}{*}{ ES } \\
\hline & \multicolumn{2}{|c|}{ Laissez-faire } & \multicolumn{2}{|c|}{ Pastoral DirectorialContractual $d$} & & & & \\
\hline Study Discipline & $\mathrm{N}=250$ & $0 \mathrm{n}_{\mathrm{o}}\left(\mathrm{n}_{\mathrm{e}}\right)$ & $\mathrm{n}_{\mathrm{o}}\left(\mathrm{n}_{\mathrm{e}}\right) \mathrm{n}_{\mathrm{o}}\left(\mathrm{n}_{\mathrm{e}}\right)$ & $\mathrm{n}_{\mathrm{o}}\left(\mathrm{n}_{\mathrm{e}}\right)$ & & & & \\
\hline Hard Discipline* & & $6(3.6)$ & $13(12.8) 5(6.8)$ & $48(48.8)$ & 12 & 3.084 & +.379 & $N S$ \\
\hline Soft Discipline** & & $6(8.4)$ & $30(30.2) 18(16.2)$ & $116(115.2)$ & & & & \\
\hline \multicolumn{9}{|l|}{ Gender } \\
\hline Male & & $10(8.5)$ & $29(30.0) 15(15.0)$ & 106(106.4) & 3 & .884 & .829 & $N S$ \\
\hline Female & & $3(4.5)$ & $17(16.0) 8(8.0)$ & $57(56.6)$ & & & & \\
\hline \multicolumn{9}{|l|}{ University Sector } \\
\hline 'Public & & $9(8.9)$ & $28(31.7) 15(15.1)$ & $118(114.3)$ & 3 & 1.757 & 7.624 & $N S$ \\
\hline Private & & $4(4.1)$ & $18(14.3) 7(6.9)$ & $48(51.7)$ & & & & \\
\hline \multicolumn{9}{|c|}{ Having Administrative Position } \\
\hline No & & $7(3.2)$ & $13(11.8) 2(5.2)$ & $41(42.9)$ & 3 & 9.552 & .023 & .209 \\
\hline 'Yes & & $4(7.8)$ & $28(29.2) 16(12.8)$ & $108(106.1)$ & & & & \\
\hline \multicolumn{9}{|l|}{ 'Age (years) } \\
\hline Young Supervisor & rs $(<35)$ & $3(2.5)$ & $10(8.6) 4(4.2)$ & $30(31.7)$ & 6 & 1.205 & 5.977 & $N S$ \\
\hline $\begin{array}{l}\text { Middle Aged (36 } \\
45)\end{array}$ & & $3(4.0)$ & $1413.8 \quad 86.7$ & $50(50.5)$ & & & & \\
\hline Aged (above 46) & & $7(6.5)$ & $21(22.6) 10(11.0)$ & $85(82.8)$ & & & & \\
\hline \multicolumn{9}{|c|}{ Postgraduate Supervision Experience } \\
\hline Novice ( $<5$ years $)$ & & $4(5.7)$ & $22(22.9) 11(11.5)$ & $86(82.9)$ & 3 & 1.460 & .692 & $N S$ \\
\hline $\begin{array}{l}\text { Experiences } \quad(> \\
\text { years) }\end{array}$ & 5 & $7(5.3)$ & $22(21.1) 11(10.5)$ & $73(76.1)$ & & & & \\
\hline
\end{tabular}


Chi-square tests of Independence were conducted to compare the proportion of expected and observed cases of supervisors under four different Supervisory Management Styles (SMS) i.e. Laissez-faire, Pastoral, Directorial and Contractual on the basis of different profile characteristics. To examine whether the SMS proportions were dependent on the different profile variables at $\alpha=.05$ level of significance. The values given in the table 4 indicated that administrative position of the supervisor was only significant factor which is associated with their supervisory management styles. It can be observed that there was a significant difference between the expected and observed frequencies, $x^{2}(3, n=219)=9.552^{\mathrm{a}}, p=.023$ with large (Pallant, 2011) effect size .209. On the basis of values given in table 4 it can be inferred that there is a significant relationship in the type SMS of supervisors they choose for supervising their supervisees at postgraduate level and their administrative responsibilities. Further, the results showed that supervisors with administrative responsibilities have more probability to adopt directorial and contractual styles of supervision while supervisors with no administrative responsibilities have probability to supervise with pastoral and Laissez-faire type of Supervisory Management Styles (SMS).

\section{Supervisory Management Styles and Supervision Characteristics of Supervisees}

Three types of background profile characteristics i.e. personal, academic and psychological) of supervisees were taken to compare their expected and observed frequencies under the membership of the four supervisory Management Styles (SMS).Chi-Square tests of Independence were applied for analyzing the relationship of Supervisory Management Styles (SMS) with different baseline supervision related background characteristics of supervisees and their effect size along with alpha $(p)$ value of significance and chi-square $\left(x^{2}\right)$ were used to interpret the results. 
Table 6

Chi-square Tests of Independence for Profile Characteristics of Supervisees and Supervisory Management Styles Adopted by Supervisors at Postgraduate Level

\begin{tabular}{|c|c|c|c|c|c|c|c|c|c|}
\hline \multirow{2}{*}{$\begin{array}{l}\text { Profile } \\
\text { Characteristics } \\
\text { of Supervisees }\end{array}$} & \multicolumn{6}{|c|}{ Supervisory Management Style } & \multirow[b]{2}{*}{ f. $x^{2}$} & \multirow[b]{2}{*}{$p$} & \multirow[b]{2}{*}{$E S$} \\
\hline & \multicolumn{2}{|c|}{ Laissez-faire } & \multicolumn{4}{|c|}{ Pastoral DirectorialContractual $d f$} & & & \\
\hline Research & $\mathrm{N}=$ & $\mathrm{n}_{\mathrm{o}}\left(\mathrm{n}_{\mathrm{e}}\right)$ & $\mathrm{n}_{\mathrm{o}}\left(\mathrm{n}_{\mathrm{e}}\right)$ & $\mathrm{n}_{\mathrm{o}}\left(\mathrm{n}_{\mathrm{e}}\right)$ & $\mathrm{n}_{\mathrm{o}}\left(\mathrm{n}_{\mathrm{e}}\right)$ & & & & \\
\hline Experience & 136 & & & & & & & & \\
\hline Yes & & $12(8.6)$ & $8(11.9)$ & $0(2.6)$ & $25(21.8)$ & 3 & 8.565 & .036 & .251 \\
\hline No & & $14(17.4)$ & $28(24.1)$ & $8(5.4)$ & $41(44.2)$ & & & & \\
\hline \multicolumn{10}{|l|}{ Gender } \\
\hline 'Male & & $6(6.1)$ & $8(8.5)$ & $2(1.9)$ & $16(15.5)$ & 3 & .065 & .996 & $N S$ \\
\hline Female & & 20(19.9) & $28(27.5)$ & $6(6.1)$ & $50(50.5)$ & & & & \\
\hline \multicolumn{10}{|l|}{ Marital Status } \\
\hline 'Single & & $14(15.6)$ & $26(25.5)$ & $6(5.7)$ & $44(43.2)$ & 3 & .703 & .873 & $N S$ \\
\hline 'Married & & $8(6.4)$ & $10(10.5)$ & $2(2.3)$ & $17(17.8)$ & & & & \\
\hline \multicolumn{10}{|l|}{ 'Candidature Type } \\
\hline Part-time & & $6(3.9)$ & $2(5.2)$ & $2(1.2)$ & $10(9.7)$ & 3 & 4.157 & .245 & $N S$ \\
\hline Full-time & & $20(22.1)$ & $32(28$. & 8)6(6.8) & $54(54.3)$ & & & & \\
\hline \multicolumn{10}{|l|}{ 'Age (years) } \\
\hline$<25$ & & $4(9.4)$ & $14(13$. & $0) 2(2.9)$ & $29(23.8)$ & 12 & 22.647 & 7.031 & .236 \\
\hline $26-30$ & & $10(9.0)$ & $10(12$ & 4) $6(2.8)$ & $21(22.8)$ & & & & \\
\hline $31-35$ & & $8(4.6)$ & $8(6.4)$ & $0(1.4)$ & $8(11.6)$ & & & & \\
\hline $35-40$ & & $4(2.7)$ & $2(3.7)$ & $0(.8)$ & $8(6.8)$ & & & & \\
\hline $40-45$ & & $0(.4)$ & $2(.5)$ & $0(.1)$ & $0(1.0)$ & & & & \\
\hline \multicolumn{10}{|c|}{ 'Supervisor allotment by } \\
\hline 'Department & & $8(5.2)$ & $4(4.4)$ & $2(1.6)$ & $8(10.8)$ & 6 & 13.038 & 8.042 & .243 \\
\hline Mutual agreemen & & $10(9.2)$ & $12(7.8$ & $0(2.8)$ & $17(19.1)$ & & & & \\
\hline Own choice & & $8(11.6)$ & $6(9.8)$ & $6(3.6)$ & $29(24.1)$ & & & & \\
\hline \multicolumn{10}{|l|}{ 'Motivation Level } \\
\hline High & & $4(9.4)$ & 1413.0 & $2(2.9)$ & $29(23.8)$ & 6 & 14.875 & 5.021 & .234 \\
\hline Normal & & $10(9.0)$ & $10(12$. & 4)6(2.8) & $21(22.8)$ & & & & \\
\hline Low & & $8(4.6)$ & $8(6.4)$ & $0(1.4)$ & $8(11.6)$ & & & & \\
\hline
\end{tabular}

Note. $\left(\mathrm{n}_{\mathrm{o}}\right)=$ Observed frequencies; $\left(\mathrm{n}_{\mathrm{e}}\right)=$ Expected frequencies; ES= Effect Size

$N=$ Total number of supervisees

Chi-square test for Independence was conducted to compare the proportion of expected and observed cases of supervisors, with four different Supervisory Management Styles (SMS) i.e. Laissez-faire, 
Pastoral, Directorial and Contractual on the basis of supervisees' personal, academic and psychological factors. The chi-square and alpha values in table 5 revealed age, previous research experience, supervisor allotment procedure and the personal motivation level of supervisees as the significant factors that found associated with the supervisors' management styles. A significant difference between the observed and expected frequencies, $x^{2}(12, n=136)=22.647, p=.031$ can be noticed. On the basis of table values it can be inferred that there is a significant difference in the expected and observed values of SMS of supervisors supervising at postgraduate level for the different age groups of supervisee which means that supervisors consider the age of their supervisees while supervising at postgraduate level. Moreover, the results showed that supervisees' previous research experience influence the style supervisors adopt to supervise their supervisees. As, the values in table 5 indicated that a significant difference was found between expected and the observed frequencies, $\chi^{2}(3, n=136)=8.565, p=.036$ with large (Pallant, 2011) effect size .251. Another, institutional factor, i.e. Supervisor Allotment Procedure indicated that there was a significant difference between the expected and observed frequencies, $\chi^{2}(6, n=136)$ $=13.038, p=.042$ with large effect size. 243. Subsequently, supervisees allotted supervisors by department were observed (over representation) in Laissez-faire and pastoral type of SMS while supervisees working with supervisors of their own choice were observed over representative in the categories of directorial and contractual type of SMS at postgraduate level. Lastly, that there was a significant difference between the expected and observed frequencies, $x^{2}(6, n=136)=14.875^{\mathrm{a}}, p=.021$ with large effect size. 234. It can be observed from the table data and values that supervisees' motivation level towards research influences the supervisory management styles of supervisors at postgraduate level. Moreover, it can be inferred from the table data that there are less chances that supervisors will use Laissez-faire SMS when supervisees' have very high motivation towards their research and vice versa (Laissez-faire and pastoral). Depending upon the higher motivation level of supervisees towards their research showed the higher number of cases in the observed proportion of supervisors that the expected number in the contractual type SMS indicated that the chances of supervision through contractual SMS increase when supervisees have higher motivation level of supervisees towards their research and vice versa (Directorial ad contractual). 


\section{Discussion and Implications of the Study}

The study empirically examined the preferred supervisory management styles of supervisors and identified a set of baseline characteristics which are associated with the preferred operating supervision management styles of supervisors at postgraduate level.

\section{Acquiring balance between hand-on and hands off supervision approaches}

The essential pedagogical aspects of supervision i.e. support and structuring the activities of research projects play significant role in the successful and timely completion of the research (Akerlind \& McAlpine, 2017). Both of these elements are offered at their higher level in contractual type of supervision style. It has been empirically verified that supervisors at postgraduate level have preferred styles of supervision and most preferably they adopt contractual type of supervision styles (Gurr, 2005). However, he emphasized to use dynamic supervision styles during the different stages of research supervision according to dynamic needs of supervisees. He further convinced that if supervisors do not make these essential changes in the supervision approaches may stifle the academic development of supervisees or becoming a cause of conflict in supervisory relationship. In some cases using static supervision approach can hinder the academic growth of supervisees.

Benmore (2016) explained the concept of supervisory roles and their transition during the research journey in a more comprehensive manner that using different supervision styles depends upon the supervisors' personal motives and candidates' experience and academic credentials. He identified primary (temporal-cognitive) and secondary (emotional, physical and relational) boundaries that suit to the specific situations and the supervisory relationship. He added that in early days of candidacy the supervisory relationship is in its infancy and the primary concern of candidates is to seek a clear direction of the research, however too much control may increase the element of dependency in students. During data collection stage a balance between monitoring progress and responding to the situations is relevant though hands-off/hands-on approach in order to develop independence in candidates. However, necessary contact and supervisor's feedback is necessary at this stage. Later on while analyzing data which is recognized as third stage (Saleem, 2014) this stage is considered conceptually more demanding hence the supervisors' more appropriate role is to become a critical friend. On the supervisees' side there may be two type of students who are pursuing their careers and 
those with having less appeal towards their career (Mason, Goulden \& Frasch, 2009) but here the supervisor's role is to be sufficiently hands off, but not hiding themselves must knowing that when and how feedback is required otherwise supervisor' absenteeism can hamper the progress of their students. At the final stage, supervisor treating their supervisees more like a critical friend, peer, committed careful editor. Management of emotional boundaries must be acknowledged by the supervisors (Benmore, 2016).

Gurr (2001) also emphasize to adopt a more dynamic approach of supervision and favored that a more directive approach is appropriate to supervise when needs to demonstrate new knowledge or application of a software or analysis is require. While in the later stages when supervisees progressed towards becoming "peer" a more hands-off approach is appropriate for supervisee's level of development. This would be result into developing confidence for decision making about project, ownership and responsibility. If supervisors do not make these essential change in the supervision approaches may stifle the academic development of supervisees or becoming a cause of conflict in supervisory relationship. In some cases using static supervision approach can hinder the academic growth of supervisees.

However, the preferred choices of supervisors towards the supervision practices make supervisors popular among the postgraduate level students but resultantly the research candidates choose for the supervisors offering best of their support and management to complete their research in successful manner. Moreover, the increased number of research candidates and supervisors willingness towards supervision of postgraduate level students has also changed their preferred styles towards supervision. But there is time to hold finger and then a time to leave supervisees to work independently. Acquiring Balance between dependence and independence and ultimately developing into competent autonomy is the scholarship of this journey. Lee (2008) explained this role of supervisor "act as bridge between the knowledge and the student and eventually they don't need me" basically pointing the development of supervisee from dependent to a competent autonomy.

\section{Supervisory Management Styles and External Factors}

Despite the fact that that adoption of a supervisory management styles is not a function of personality traits but more likely they are influenced by the external factors (Gatfield, 2005). For instance the nature difficulties that a novice supervisor faces are different from the experienced and the other supervisor characteristics (de Kleijn, Meijer, 
Pilot \& Brekelmans, 2014). The studies conducted in local context highlight the importance of supervisees' personal and institutional characteristics i.e. mutual alignment between a supervisee's research topic and his/her supervisor's area of specialization, stage of research and study disciple in managing research projects and providing support during research (Saleem \& Mahmood, 2017; Saleem \& Mahmood, 2018)

Hence, investigating the supervisors' characteristics which can be associated with Supervisory Management Styles identified some significant factors. The personal characteristic and institutional characteristic were taken into consideration. The significant association between supervisor's administrative position and adoption of supervision style implicate the importance of institutional factors over the personal characteristics. While supervisors with administrative responsibilities reported as more likely to adopt directorial and contractual styles of supervision while supervisors with no administrative responsibilities are more likely to supervise with pastoral and Laissez-faire type of Supervisory Management Styles (SMS) can be result of pedagogical choices of supervisors associated with their supervision practices. Moreover, this factor is more relevant in our context due to the importance of acquiring an administrative position at higher education level.

\section{Background Profile of Supervisee and Supervisory Management Styles}

Three type of profile characteristics (i.e. personal, academic and psychological) of supervisees were taken into consideration while examining their association with Supervisory Management Styles. Suppositions were made regarding the preferred operating style of supervisors depending upon the attitude and responses of candidates (Gatfield, 2005) but no empirical traces were found to make any implications for future researchers. Hence, the research proved the influence of supervisees' age (as personal factor), previous research experience, the procedure through which they have been allotted supervisors (as academic factors) and their personal motivation towards research (as psychological) in adopting preferred operating styles of supervision for supervisors. It can be concluded that adoption of a particular supervision style by supervisors is more influenced by the characteristics of supervisees instead of their own personal characteristics. This made a thought provoking implications for the administrators and leaders at higher education level that in order to make supervision workable for supervisors they need to consider the external 
factors that influence their choices towards supervision practices. In some researches on doctoral supervision the associated background variables have been identified like Hockey (1991) pointed out some personal attributes of research candidates while selecting them to supervise i.e. strong motivation towards research, independence, self confidence, persistence and ability of judgment. Some researchers also emphasized the importance of various stages in research supervision addressing the dynamic needs of supervisees through using different supervision styles (Aranda-Mena \&Gameson, 2009; Boehe , 2016; Grant, 2003; Saleem \& Mahmood, 2018)

Gatfield (2005) also acknowledged the relevance of supervisory styles with "external" factors which are related to the individuals' aspects like motivation, research skills and maturity level. Moreover, adoption of a style by supervisor is also influenced by the characteristics of supervisees and their particular stage of research. In other researches (Aranda-Mena \&Gameson, 2012; Boehe, 2016; Grant, 2003; Gurr, 2001) acknowledged the dynamic needs of supervisees and use of different styles has been considered appropriate at specific times with specific purposes. However, students' motivation and their previous research experience can be used to get best out of their work and development of skills in them but use of different styles has been considered appropriate at specific time with specific purposes.

\section{Conclusion and Recommendations}

Supervisors' tilt towards adopting contractual supervision style as most preferred operating style of supervision through various research stages during supervision can be attributed as the static approach of supervisors towards responding the dynamic needs of supervisees. Considering contractual style as the most preferred supervisory management style and solution for the problems throughout the whole research journey not only results into a more hand-holding approach of supervisors to respond the supervisees' problems but also keep their supervisees to stay dependent on them till the end of research. Consequently, the scholars of such prestigious degree couldn't be able to develop the state of competent autonomy (Gurr, 2001) which is the perceived product of this degree. Subsequently, this approach is also setting a trend in research candidates to expect undue favors from their supervisors even when something needs to be done by them. A trend of replication studies (Javed, 2012) is the evidence of such research and hand-holding supervision practices as low hanging fruit. Using a static supervision styles can reduce the academic growth of research 
candidates. Supervisors may be trained to use different styles according to the benefits associated with their use in different situations and for supervisees with different background profiles. In-house institution based skill development programme can be offered by Higher Education Commission (HEC) with certifications to encourage supervisors to use new methodologies and research techniques creatively instead of conducting replication studies with highly structured supervision styles in order to avoid uncertainty.

Mostly supervisors at postgraduate level are overloaded with the other institutional administrative duties due to which the association between supervisors' administrative position enable them to handle the administrative hurdles and support their supervisees due to strong institutional positions and administrative powers. Being able to hold the procedural complexities keep the research projects of their supervisees in order and results into timely completion in smooth way but also diminish the space for creativity and supervisees' motivation to own their work and to handle the associated problems independently. Supervisors may also consider the outcomes of their experiences with different supervisees to evaluate the appropriateness of their expected milestones and support mechanism towards supervisees with different characteristics instead of providing un-necessary support and over ruling to meet deadlines. 


\section{References}

Abdullah, M. N. L. Y., \& Evans, T. (2012). The relationships between postgraduate research students' psychological attributes and their supervisors' supervision training. Procedia-Social and Behavioral Sciences, 31, 788-793.

Åkerlind, G., \& McAlpine, L. (2017). Supervising doctoral students: Variation in purpose and pedagogy. Studies in Higher Education, 42(9), 1686-1698.

Anderson, J. (1988). The supervisory process in speech, language pathology and audiology. Boston: College Hill Press.

Aranda-Mena, G., \& Gameson, R. (2012). An alignment model for the research higher degree supervision process using repertory gridsreflections on application in practice in built environment research. Construction Economics and Building, 12(3), 66-81.

Benmore, A. (2016). Boundary management in doctoral supervision: how supervisors negotiate roles and role transitions throughout the supervisory journey. Studies in Higher Education, 41(7), 1251-1264.

Blass, E., Jasman, A., \& Levy, R. (2012). Supervisor reflections on developing doctoralness in practice-based doctoral students. Quality Assurance in Education, 20(1), 31-41.

Blake, R., and Mouton, J. (1964). The managerial grid. Houston, TX: Gulf Publishing.

Boehe, D. M. (2016). Supervisory styles: A contingency framework. Studies in Higher Education, 41(3), 399-414.

Cantwell, R. H., Bourke, S. F., Scevak, J. J., Holbrook, A. P., \& Budd, J. (2017). Doctoral candidates as learners: a study of individual differences in responses to learning and its management. Studies in Higher Education, 42(1), 47-64.

Creswell, J. W., Plano Clark, V. L., Gutmann, M. L., \& Hanson, W. E. (2003). Advanced mixed methods research designs. Handbook of mixed methods in social and behavioral research, 209, 240. 
Deuchar, R. (2008). Facilitator, director or critical friend? contradiction and congruence in doctoral supervision styles. Teaching in Higher Education, 13(4), 489-500.

Gatfield, T. (2005). An investigation into PhD supervisory management styles: Development of a dynamic conceptual model and its managerial implications. Journal of Higher Education Policy and Management, 27(3), 311-325.

Grant, B. (1999). Walking on a rackety bridge: mapping supervision. Paper presented at the HERDSA Annual International Conference, Melbourne.

Grant, B. (2003). Mapping the pleasures and risks of supervision. Discourse: Studies in the Cultural Politics of Education, 2, 175-190.

Grant, B. (2005). Fighting for space in supervision: Fantasies, fairytales, fictions and fallacies. International Journal of Qualitative Studies in Education, 18 (3), 337-54.

Gurr, G. (2001). Negotiating the 'rickety bridge': A dynamic model for aligning supervisory style with research student development. Higher Education Research and Development, 20 (1), 81-92.

Gravetter, F. J., \& Wallnau, L. B. (2004). Statistics for the behavioral sciences (6th ed.). Belmont, CA7 Wadsworth.

Hemer, S. R. (2012). Informality, power and relationships in postgraduate supervision: Supervising $\mathrm{PhD}$ candidates over coffee. Higher Education Research \& Development, 31(6), 827-839.

Holbrook, A., Shaw, K., Scevak, J., Bourke, S., Cantwell, R., \& Budd, J. (2014). PhD candidate expectations: Exploring mismatch with experience. International Journal of Doctoral Studies, 9, 329-346.

Higher Education Commission. (HEC, 2016). Statistical information unit. Retrieved from, http://www.hec.gov.pk/InsideHEC/Divisions/QALI/Others/Pages/Sta tisticalInformationUnit.aspx

Hockey, J. (1991). The social science PhD: a literature review. Studies in Higher Education, 16 (3), 319-332. 
Ives, G. \& Rowley, G. (2005). Supervisor selection or allocation and continuity of supervision: Ph.D students' progress and outcomes. Studies in Higher Education, 30 (5), 535-555.

Javed, U. (2014, January 6). Reversing the rot. Dawn News. Retrieved from http://www.dawn.com/news/1078612

Kam, B.H. (1997). Style and quality in research supervision. Higher Education, 34 (1), 81-103.

Landis J, Koch G. (1977). The measurement of observer agreement for categorical data. Biometrics, 33, 159-174.

Lee, A. (2007). Developing effective supervisors. South African Journal of Higher Education, 21(4), 680-93.

Lee, A. (2008). How are doctoral students supervised? Concepts of doctoral research supervision. Studies in Higher Education,33(3), 267-281.

Malfroy, J. (2005). Doctoral supervision, workplace research and changing pedagogic practices. Higher Education Research \& Development, 24(2), 165-178.

Mason, M. A., Goulden, M., \& Frasch, K. (2009). Why graduate students reject the fast track. Academe, 95(1), 11-16.

Mainhard, T., Van Der Rijst, R., Van Tartwijk, J., \& Wubbels, T. (2009) A model for the supervisor-doctoral student relationship. Higher education,58(3), 359-373.

McAlpine, L., \& McKinnon, M. (2013). Supervision-the most variable of variables: Student perspectives. Studies in Continuing Education, 35(3), 265-280.

Moriarty, B., Danaher, P. A., \& Danaher, G. (2008). Freire and dialogical pedagogy: A means for interrogating opportunities and challenges in Australian postgraduate supervision. International Journal of Lifelong Education,27(4), 431-442.

Murphy, N., Bain, J. D., \& Conrad, L. (2007). Orientations to research higher degree supervision. Higher Education,53(2), 209-234. 
Pallant, J. (2011). SPSS survival manual, 4th ed. Crows Nest: Allen \& Unwin.

Parry, S., and Hayden, M. (1994). Supervising higher degree research students: An investigation of practices across a range of academic departments. Australia: Commonwealth of Australia.

Saleem, T. (2014). Impact of supervisor-supervisee relationship on the quality of supervision at postgraduate level. Unpublished MPhil thesis, submitted at University of the Punjab, Lahore.

Saleem, T., \& Mahmood, N. (2017). Influence of the Supervision Related Background Variables on the Supervisees' Supervision Experiences at Postgraduate Level.Pakistan Journal of Education,34(2), 73-99.

Saleem, T., \& Mahmood, N. (2018). Assessing the Quality of Supervision Experiences in the Different Research Stages at Postgraduate Level. Journal of Education and Educational Development, 5(2), 8-27.

Taylor, R. T., Vitale, T., Tapoler, C., \& Whaley, K. (2018). Desirable qualities of modern doctorate advisors in the USA: a view through the lenses of candidates, graduates, and academic advisors. Studies in Higher Education,43(5), 854-866.

Turner, G. (2015). Learning to supervise: Four journeys. Innovations in Education and Teaching International,52(1), 86-98.

Wright, T., \& Cochrane, R. (2000). Factors influencing successful submission of $\mathrm{PhD}$ Theses. Studies in Higher Education, 25, 181195.

\section{Citation of this Article:}

Saleem, T., \& Rana, R.A. (2019). An empirical investigation of supervisory management styles and associated factors for postgraduate level research supervision. Pakistan Journal of Education, 36(3), 91-117. DOI: $10.30971 /$ pje.v36i3.828.g200

To link this article: http://dx.doi.org/10.30971/pje.v36i3.828 